\title{
Classical Kawasaki disease in a neonate
}

\author{
T V Stanley, K Grimwood
}

Arch Dis Child Fetal Neonatal Ed 2002;86:F135-F136

A case is reported of classical Kawasaki disease in an infant younger than 2 weeks of age. Echocardiography detected a coronary artery aneurysm on the fifth day of the illness. Administration of intravenous $\gamma$ globulin resulted in rapid improvement. Kawasaki disease is rare in neonates, but it may follow a rapid and severe course.

$\mathrm{K}$ awasaki disease $(\mathrm{KD})$ is unusual in newborn infants. Of 105755 patients with KD registered in Japan over 25 days. ${ }^{1}$ years, only six were neonates, with the youngest aged 20

\section{CASE REPORT}

A full term, breastfed male infant, the only child of healthy, non-consanguineous parents, presented at 12 days of age after 48 hours of fever, irritability, and poor feeding. A generalised rash had developed 12 hours earlier. Pregnancy and delivery were normal, birth weight was $3080 \mathrm{~g}$, and he had been well post partum. His temperature was $38.5^{\circ} \mathrm{C}$, pulse $166 /$ minute, respiration 52/minute, capillary refill less than two seconds, and weight $3400 \mathrm{~g}$. He was drowsy and irritable with a high pitched cry. The fontanelle was soft and muscle tone was normal. A generalised non-tender, non-blistering, erythematous rash was present. The remaining examination was unremarkable.

Laboratory investigations included: haemoglobin $132 \mathrm{~g} / \mathrm{l}$, white blood cells $5.4 \times 10^{9} / 1$ (neutrophils $39 \%$, lymphocytes $39 \%$, monocytes $22 \%$ ), platelets $251 \times 10^{9} /$, sodium 135 $\mathrm{mmol} / \mathrm{l}$, potassium $4.7 \mathrm{mmol} / \mathrm{l}$, calcium $2.6 \mathrm{mmol} / \mathrm{l}$, creatinine $52 \mu \mathrm{mol} / \mathrm{l}$, glucose $4.8 \mathrm{mmol} / \mathrm{l}$, total bilirubin $101 \mu \mathrm{mol} / \mathrm{l}$, albumin $30 \mathrm{~g} / \mathrm{l}$, C reactive protein $0 \mathrm{mg} / \mathrm{l}$. Cerebrospinal fluid contained $3 \times 10^{6} / 1$ white blood cells, $1 \times 10^{6} / 1$ red blood cells, protein $0.43 \mathrm{~g} / \mathrm{l}$, and glucose $2.1 \mathrm{mmol} / \mathrm{l}$. Catheter urine was analysed as follows: $\mathrm{pH} 5.0,<10 \times 10^{6} / 1$ white blood cells; no red blood cells, protein, or bacteria were detected.

The infant received amoxicillin and gentamicin, but eight hours later developed apnoea and multifocal clonic seizures. Phenobarbitone, phenytoin, flucloxacillin, and acyclovir were added, and assisted ventilation was started. Chest radiographs and computed tomography brain scans were normal, as were arterial $\mathrm{pH}$, serum ammonia, lactate, and urine metabolic screening tests.

The rash spread next day to involve the palms and soles. The hands and feet became swollen. By the third hospital day, bilateral non-exudative conjunctivitis, erythematous dry lips, and a "red raspberry" tongue appeared. Echocardiography showed a dilated $(3.5 \mathrm{~mm})$ left coronary artery with a small aneurysm in its proximal segment. An electrocardiogram was normal. Intravenous $\gamma$ globulin $(2 \mathrm{~g} / \mathrm{kg}$ ) was given. Within 24 hours, the patient became afebrile and less irritable, the rash faded, and he was extubated. Low dose aspirin ( $5 \mathrm{mg} / \mathrm{kg}$ ) was started. By the 5 th day he was more alert. His hands and feet were no longer swollen, the rash and oral changes had resolved, and his conjunctivitis had improved. After seven days, the platelet count reached $677 \times 10^{9} / \mathrm{l}$, while neutrophil numbers fell to $0.4 \times 10^{9} / 1$ before recovering over two weeks.
Periungual desquamation began on day 10 and continued for two weeks.

Bacterial cultures from blood, urine, and cerebrospinal fluid were sterile. The antimicrobial agents were discontinued within 24 hours of the start of $\gamma$ globulin. Viral cultures from the nasopharynx, urine, and faeces and polymerase chain reaction tests for herpes simplex, enteroviruses, Epstein-Barr virus, and parvovirus from blood and cerebrospinal fluid were negative. Epstein-Barr virus and parvovirus IgG, but not IgM, antibodies were detected. His mother's syphilis serology was non-reactive.

The patient was discharged on aspirin after nine days in hospital. The aneurysm resolved by six weeks. Two and a half years later he is well, without cardiac or neurodevelopmental symptoms. The left coronary artery dilatation persists (3.5 $\mathrm{mm}$ ) and he continues to take aspirin.

\section{DISCUSSION}

Two other neonates have presented with KD before age 2 weeks. ${ }^{23}$ The first collapsed and died within four hours of birth. At necropsy, acute coronary artery vasculitis, vessel obstruction by fresh thrombus, and a recent myocardial infarction was found. ${ }^{2}$ In the second case, the patient became febrile at five days and rapidly developed heart failure. He had myocarditis, dilated left coronary arteries, and raised C reactive protein. After being given $\gamma$ globulin, he recovered, with resolution of the echocardiographic coronary artery abnormalities.

Neither infant had classical features of KD (fever for five days or more with conjunctivitis, mucositis, extremity changes, rash with or without cervical lymphadenopathy). The diagnosis was based on cardiac abnormalities at autopsy or by echocardiography. Similar circumstances are seen in older infants with fever and less than four diagnostic features who develop coronary artery aneurysms. These patients have incomplete $\mathrm{KD}$, which is a challenging diagnosis in young infants who are among the most susceptible to cardiac complications. ${ }^{4}$

In contrast, our patient fulfilled the clinical diagnostic criteria and also had echocardiographic coronary artery abnormalities. No alternative disorder was identified and he improved rapidly with high dose $\gamma$ globulin. His lethargy, irritability, abnormal cry, seizures, and severe apnoea suggested involvement of the central nervous system. He did not have aseptic meningitis, which is often reported in patients with KD. Other neurological complications such as encephalopathy, seizures, cerebrovascular events, and isolated cranial nerve deficits are uncommon. Transient cerebral hypoperfusion has been observed during the acute phase of the illness, and it is postulated that vasculitis may cause these rare neurological manifestations.

Although raised serum acute phase reactants are almost universal, more than $50 \%$ of patients with $\mathrm{KD}$ do not have increased $\mathrm{C}$ reactive protein at diagnosis. ${ }^{6}$ Transient neutropenia is uncommon. In this patient it preceded the administration of $\gamma$ globulin and aspirin, both of which have been implicated in a causal role. Presumably his young age, early diagnosis, and treatment may explain these findings. 
The rarity of KD in neonates is consistent with epidemiological evidence that infectious agents cause this disease. Paediatricians and neonatologists should be aware that KD occurs in neonates, that the presentation may be atypical, and that it can follow a rapid and severe course.

\section{Authors' affiliations}

T V Stanley, K Grimwood, Department of Paediatrics and Child Health, Wellington School of Medicine and Health Sciences, Wellington, New Zealand

Correspondence to: Professor Grimwood, Department of Paediatrics and Child Health, Wellington School of Medicine, Wellington, New Zealand 6015; grimwood@wnmeds.ac.nz

Accepted 6 December 2001

\section{REFERENCES}

1 Tsuchida S, Yamanaka T, Tsuchida R, et al. Epidemiology of infant Kawasaki disease with a report of the youngest neonatal case ever reported in Japan. Acta Paediatr 1996;85:995-7.

2 Krapf R, Zimmermann A, Stocker F. Lethal vasculitis of coronary arteries in a neonate and two infants: possible neonatal variant of the MLNS/IPN complex? Helv Paediatr Acta 1981;36:589-98

3 Bolz D, Arbenz U, Fanconi S, et al. Myocarditis and coronary dilatation in the 1st week of life: neonatal incomplete Kawasaki disease? Eur J Pediatr 1998;157:589-91.

4 Joffe A, Kabani A, Jadavii T. Atypical and complicated Kawasaki disease in infants. Do we need criteria? West J Med 1995;162:322-7.

5 Ichiyama T, Nishikawa M, Hayashi T, et al. Cerebral hypoperfusion during acute Kawasaki disease. Stroke 1998;29:1320-1.

6 Koyanagi $\mathbf{H}$, Yanagawa $H$, Nakamura $Y$, et al. Serum C-reactive protein levels in patients with Kawasaki disease: from the results of nation-wide surveys of Kawasaki disease in Japan. Acta Paediatr 1997;86:613-19.

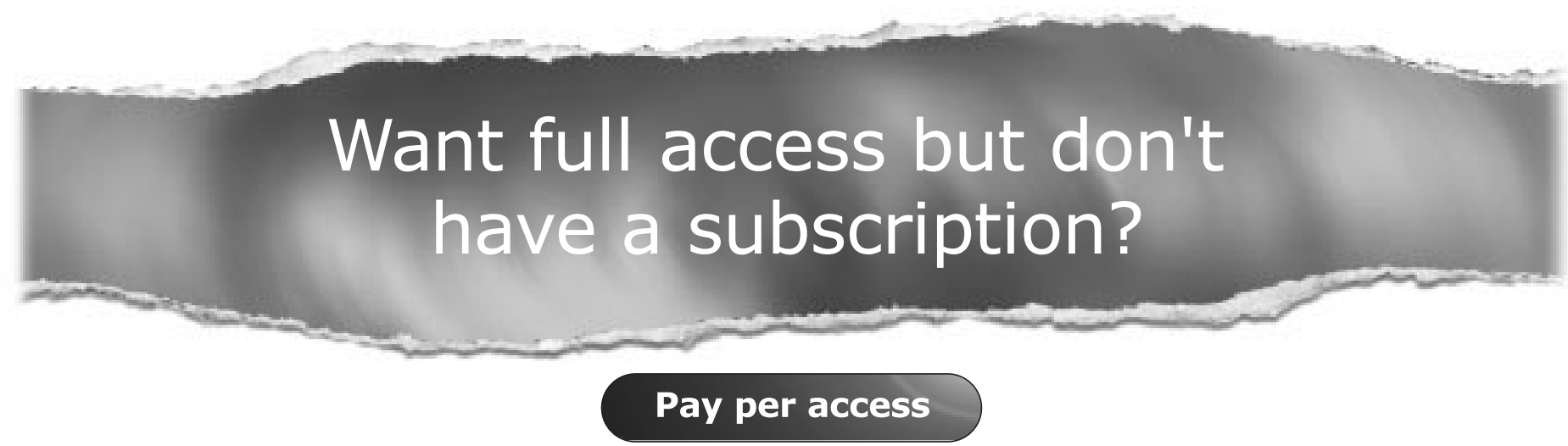

For just US $\$ 25$ you can have instant access to the whole website for 30 days. During this time you will be able to access the full text for all issues (including supplements) available. You will also be able to download and print any relevant pdf files for personal use, and take advantage of all the special features Archives of Disease in Childhood online has to offer.

\section{www.archdischild.com}

